\title{
Macro and trace elements in edible mushrooms, Shiitake, Shimeji and Cardoncello from Petrópolis, Rio de Janeiro, Brazil
}

\author{
Macro e elementos-traço em cogumelos comestíveis, Shiitake, Shimeji e Cardoncello, \\ coletados em Petrópolis, Rio de Janeiro, Brasil
}

\author{
Jaylei Monteiro Gonçalves $^{*}$ Monique Dias Corrêa de Souza $^{\text {II }}$ Rafael Christian Chavez Rocha ${ }^{\text {III }}$ \\ Renata Jurema Medeiros ${ }^{\mathrm{IV}}$ Silvana do Couto Jacob $^{\mathrm{I}}$
}

\section{ABSTRACT}

The concentrations of twenty-five elements ( $\mathrm{Al}$, As, $\mathrm{Ba}, \mathrm{Bi}, \mathrm{Ca}, \mathrm{Cd}, \mathrm{Cr}, \mathrm{Cu}, \mathrm{Fe}, \mathrm{Ga}, \mathrm{K}, \mathrm{Li}, \mathrm{Mg}, \mathrm{Mn}, \mathrm{Mo}, \mathrm{Na}$, $\mathrm{Ni}, \mathrm{Pb}, \mathrm{Rb}, \mathrm{Sb}, \mathrm{Se}, \mathrm{Sn}, \mathrm{Sr}, \mathrm{V}$ and $\mathrm{Zn}$ ) were determined in three edible mushrooms, Shiitake (Lentinula edodes), Black Shimeji (Pleurotus ostreatus) and Cardoncello (Pleurotus eryngyii) from Petrópolis, Rio de Janeiro, Brazil. Samples were collected along the year 2010 and their preparations were made after drying, milling, an acid pre-digestion and a decomposition procedure in a muffle furnace. The analytical techniques employed for the elements determination were Mass Spectrometry with Inductively Coupled Plasma and Flame Atomic Absorption Spectrometry. Two certified reference materials, Apple Leaves and Mussel Tissue, were used for the evaluation of the analytical procedure and recovery values around $98 \%$ were obtained. The results showed that the analyzed mushrooms have high levels of $\mathrm{Cu}, \mathrm{Fe}, \mathrm{K}, \mathrm{Mg}$, $\mathrm{Mn}$ and $\mathrm{Zn}$ containing more than $30 \%$ the recommended daily intake for these nutrients according to Brazilian legislation. These mushrooms presented a very low ratio $\mathrm{Na} / \mathrm{K}$. Regarding the levels of some contaminants, the mushrooms had concentrations of $C d$, $\mathrm{Pb}$ and As below the recommended maximum limits allowed by Brazilian legislation.

Key words: edible mushroom, nutrients, contaminants.

RESUMO

As concentrações de vinte e cinco elementos ( $\mathrm{Al}$, As, $\mathrm{Ba}, \mathrm{Bi}, \mathrm{Ca}, \mathrm{Cd}, \mathrm{Cr}, \mathrm{Cu}, \mathrm{Fe}, \mathrm{Ga}, \mathrm{K}, \mathrm{Li}, \mathrm{Mg}, \mathrm{Mn}, \mathrm{Mo}, \mathrm{Na}, \mathrm{Ni}, \mathrm{Pb}$, $\mathrm{Rb}$, Sb, Se, Sn, Sr, V e Zn) foram determinadas em três cogumelos comestíveis, Lentinula edodes (Shiitake), Pleurotus ostreatus (Shimeji preto) e Pleurotus eryngii (Cardoncello) provenientes de Petrópolis, Rio de Janeiro, Brasil. As amostras foram coletadas durante o ano de 2010 e o preparo efetuado por secagem, trituração, pré-digestão ácida e mineralização em mufla. As técnicas analíticas utilizadas na determinação dos elementos foram a espectrometria de massa com plasma indutivamente acoplado e a absorção atômica com chama. Dois materiais de referência certificados, Apple Leaves e Mussel Tissue, foram utilizados para a avaliação do procedimento analítico e valores de recuperação em torno de $98 \%$ foram obtidos. Os resultados demonstraram que os cogumelos estudados apresentam altos teores $\mathrm{de} \mathrm{Cu}, \mathrm{Fe}, \mathrm{K}, \mathrm{Mg}$, Mn e Zn, contendo mais de 30\% das quantidades recomendadas para ingestão diária desses nutrientes, conforme a legislação brasileira. Esses cogumelos possuem uma razão Na/K muito baixa e os níveis de alguns contaminantes, $\mathrm{Cd}$, Pb e As, estão abaixo dos limites máximos permitidos pela legislação em vigor.

Palavras-chave: cogumelo comestível, nutrientes, contaminantes.

\section{INTRODUCTION}

The use of mushrooms as source of nutrients or in therapeutics is old and crops for commercial purposes are described since sixth century. Commercial cultivation in Brazil is much more recent, initiated in the 50's from the production of Agaricus bisporus, commonly known as Champignon, in Mogi das Cruzes, São Paulo (BONONI, 2003).

Worldwide, the production of cultivated mushrooms is approximately 3.5 million metric tons, about 26 times lower than the production of meat that is about 88 million metric tons. In Brazil, per capita consumption of mushrooms is low, about 70 to 160

Instituto Nacional de Controle de Qualidade em Saúde (INCQS), Fundação Oswaldo Cruz (FIOCRUZ), Av. Brasil, 4365, 21040-900, Manguinhos, RJ, Brasil. E-mail: jaylei.goncalves@incqs.fiocruz.br. *Autor para correspondência.

IIGeoquímica Ambiental, Departamento de Geoquímica, Universidade Federal Fluminense (UFF), Outeiro de São João Batista, Niterói, RJ, Brasil.

IILLabSpectro, Pontifícia Universidade Católica (PUC), Gávea, RJ, Brasil.

${ }^{\text {IV L}}$ Laboratório de Experimentação Animal (LAEAN), FIOCRUZ, Manguinhos, RJ, Brasil. Received 03.19.13 Approved 09.10.13 Returned by the author 03.19.14 CR-2013-0366.R2 
grams habitant ${ }^{-1}$ year $^{-1}$, when compared with other countries like China, $10 \mathrm{~kg}$ habitant ${ }^{-1}$ year $^{-1}$ (KALAČ AND SVABODA, 2000). Just for comparison, per capita consumption of meat (beef and pork) in Brazil is $71 \mathrm{~kg}$ year ${ }^{-1}$ while in China is $45 \mathrm{~kg} /$ year (FAO, 2003).

The species of mushrooms most widely cultivated and commercialized are "Champignon" which corresponds about $38 \%$ of the global market, followed by the species of the genus Pleurotus like Pleurotus ostreatus, known as Shimeji, which correspond for about $25 \%$ of this market. Lentinula edodes, known as Shiitake, appears in third place, which correspond around 10\%. Brazil follows the order of cultivation and consumption of the species mentioned above, however "Champignon" is responsible for almost all domestic production which is about 3 metric tons/ year (VILELA, 2007).

Climate, culture factors and price limit the consumption of mushrooms in Brazil. The prevalence of tropical climate does not favor the growth of many edible species, the cultural pattern does not include mushrooms in regional recipes and in Brazil the mushrooms have high cost due to low productivity. Although these facts, the consumption has increased steadily since the last decade due to the adoption of habits coming from other regions of the globe, such as Japan, the inclusion of mushrooms as a sophisticated food and the adoption of public policies intended to train producers in mushroom cultivation (URBEN, 2004).

Under the nutritional aspect, mushrooms are a good source of protein, vitamins and inorganic elements like phosphorus, potassium, selenium, zinc, magnesium, copper (SADLER, 2003). MICHELOT et al. (1998) studied fifteen species from France, in the Paris region, reporting concentrations in the range of 340-1440 (Ca), 3-4 (Cd), 28-80 (Fe), 3-34 (Mn) 52-67 (Zn) $\mathrm{mg} \mathrm{kg}^{-1} \mathrm{dw}$. ZHU et al (2003) investigated wild edible mushrooms from a Province of China and found concentrations ranged from 0.06 to12.9 $(\mathrm{Cd}$, $\mathrm{Pb}$ and $\mathrm{Ni}$ ) and 6.83 to $57.9(\mathrm{Cu}, \mathrm{Zn}, \mathrm{Mn}$ and $\mathrm{Cr}$ ) and 95.7 to $242(\mathrm{Fe}) \mathrm{mg} \mathrm{kg}^{-1} \mathrm{dw}$. In a recent review from KALAČ (2010) the usual contents of four major elements reported from years 2000 to 2009 in European species are 100-400 (Na), 20000-40000 (K), 100-500 (Ca) and 800-1800 (Mg) mg kg-1 dw. In a complementary work, KALAČ (2010) reported trace elements concentrations in the range of 20-150 (Al), 0,5-5 (As), 2-4 (Ba), 1-5 (Cd), 0,5-5 (Cr), 20$100(\mathrm{Cu}), 25-200(\mathrm{Zn})$ and 50-300 (Fe) $\mathrm{mg} \mathrm{kg}^{-1} \mathrm{dw}$.

About the methods used for the determination of elements contents, MICHELOT and ZHU, used Inductively Coupled Plasma Optical Emission Spectrometry by (ICP-OES) but according to KALAČ (2010), Atomic Absorption Spectrometry (AAS) is the most wide-spread method. Nevertheless, there are reports about the use of another techniques: Inductively Coupled Plasma Mass Spectrometry (ICP-MS), Anodic Stripping Voltametry (ASV) and Neutron Activation Analysis (NAA).

As pointed out by MOURA (2008), whom used the NAA technique, despite the existence of several works in others countries regarding the chemical composition of edible mushrooms, there are still few studies about their nutritional value. Therefore, the present study aimed to assess the nutritional importance of three species of mushrooms consumed in Brazil by evaluating the levels of inorganic trace elements.

\section{MATERIALS AND METHODS}

Samples of Shiitake, Shimeji and Cardoncello (Pleurotus eryngyii) were acquired at Cogumelos Imperial, a mushroom cultivation in the neighborhood of Rocio in Petropolis. The substrate used was composed by $80-90 \%$ residual of eucalyptus $\log$ (sawdust) and $10-20 \%$ of rice bran and wheat bran added of Gypsum or dolomite to obtain a $\mathrm{pH}$ 4. The substrate mixture used was dependent on the mushroom specie.

The samples were collected along the year of 2010, four samplings, and the amount collected was approximately 1 kilogram of each mushroom. The samples were washed and after drying in oven at $50^{\circ} \mathrm{C}$ during 4 hours, they were packaged with a low density polyethylene plastic envelops and then taken to the laboratory where they were stored in refrigerator under $7^{\circ} \mathrm{C}$ overnight.

To determine the moisture content of mushrooms, approximately $5 \mathrm{~g}$ of each fresh mushroom $(n=5)$ were weighed, oven dried at $90^{\circ} \mathrm{C}$ during 2 hours. Afterwards they were kept in a desiccator until reach room temperature. The procedure was performed twice.

To proceed the analysis, the samples were dried in oven at $90^{\circ} \mathrm{C}$ for 2 hours, grounded in domestic processor and packed in polypropylene plastic bottles. After drying, a pre-digestion of ten aliquots of $0.5 \mathrm{~g}$ from each mushroom collected along the year of 2010 were performed with concentrated $\mathrm{HNO}_{3}$ (Suprapur Merck) and heated in a hot plate for $4 \mathrm{~h}$. Than, the samples were ashed during 12 hours in an oven at $500^{\circ} \mathrm{C}$. The ashes were dissolved with $10 \mathrm{~mL}$ of $10 \% \mathrm{w} / \mathrm{v}$ and transfer with deionized 
water (Milli-Q Millipore $18.2 \mathrm{M} \Omega \mathrm{cm}^{-1}$ resistivity) for polypropylene bottles in a final volume of $15 \mathrm{~mL}$. Blank solutions of the reagents and replicates $(n=5)$ of certified reference materials, Apple Leaves NIST n.1515 and Mussel Tissue from National Institute of Standards and Technology (NIST) n.2976, were made in each digestion procedure to ensure the quality of results. The quantification of inorganic elements was performed with Inductively Coupled Plasma Mass Spectrometer (ICP-MS) model 2 X-Series - Thermo Scientific and a Flame Atomic Absorption Spectrometer (FAAS), model AA400, Perkin Elmer.

\section{RESULTS AND DISCUSSION}

The performance of the analytical procedure was evaluated by analyzing the certified reference material (RCM) and for most elements were found concentrations consistent with expected values, they were between $88-102 \%$ of certified values. The relative standard deviation of the method was evaluated by analyzing five individual aliquots from the two RCM and for all elements analyzed it was between 2 and $11 \%$.

There were no significant variations in elements concentrations for all mushroom species. It could be attributed to similar environmental conditions of cultivation and substrate composition, even so, some variability was observed. The small variations between mushrooms species were not constant and this may perhaps due to the size and weight of mushrooms collected, factors that were not considered in this study.

The average moisture content of studied species was approximately 90\%: Shiitake, 90,8 11,1 ; Shimeji, 90,1 $\pm 1,4$ and Cardoncello, 88,9 $\pm 0,9$. The average levels of the elements in each mushroom are on a dry weight basis and summarized in tables 1 and 2. Shimeji presented highest concentrations of $\mathrm{Ba}, \mathrm{Ni}, \mathrm{As}, \mathrm{Bi}, \mathrm{Cr}, \mathrm{Ca}, \mathrm{Ga}, \mathrm{Mo}, \mathrm{Sb}, \mathrm{Se}, \mathrm{Sr}, \mathrm{Sn}, \mathrm{V}$ and $\mathrm{K}$, followed by Shiitake with higher levels of $\mathrm{Cd}, \mathrm{Cr}$, $\mathrm{Pb}, \mathrm{Sn}, \mathrm{Mn}, \mathrm{Zn}, \mathrm{Na}$ and $\mathrm{Mg}$, and Cardoncello with higher levels of $\mathrm{Li}, \mathrm{V}, \mathrm{Fe}, \mathrm{Rb}, \mathrm{Ca}$ and $\mathrm{Al}$. The results for Shiitake samples were discordant for the following elements: Ga, Mo and Sn. The $3^{\text {rd }}$ sampling had lower values for $\mathrm{Ga}-0.087 \mathrm{mg} \mathrm{kg}^{-1} \mathrm{dw}$, higher values in the $4^{\text {th }}$ collection for Mo - $1.24 \mathrm{mg} \mathrm{kg}^{-1} \mathrm{dw}$, and higher values in the second collection for $\mathrm{Sn}-0.206 \mathrm{mg} \mathrm{kg}^{-1} \mathrm{dw}$.

The results showed the macro and micronutrients with higher variability concentration among the four sampling were: $\mathrm{Zn}-74,134,82$, $158 \mathrm{mg} \mathrm{kg}^{-1} \mathrm{dw}$ and $\mathrm{Cu}-2.3,1.7,12.5,7.4 \mathrm{mg} \mathrm{kg}^{-1}$ $\mathrm{dw}$. Shimeji species presented variations only for two elements: Se - 0.078, 0.16, 0.123, 0.040, and Al - 51, $115,114,50 \mathrm{mg} \mathrm{kg}^{-1} \mathrm{dw}$.

Each species of mushroom has been classified by comparing the amount of nutrients with the value of the Recommended Daily Intake (RDI) according to Brazilian legislation (BRASIL, 2005) in which a food is considered a nutrient source when a minimum of $15 \%$ of RDI in $100 \mathrm{~g}$ is reached and a high level source of nutrient with at least $30 \%$ of $\mathrm{RDI}$ in $100 \mathrm{~g}$. In agreement with this legislation,

Table 1 - Micronutrients and trace-elements concentration in Shiitake, Shimeji and Cardoncello mushrooms.

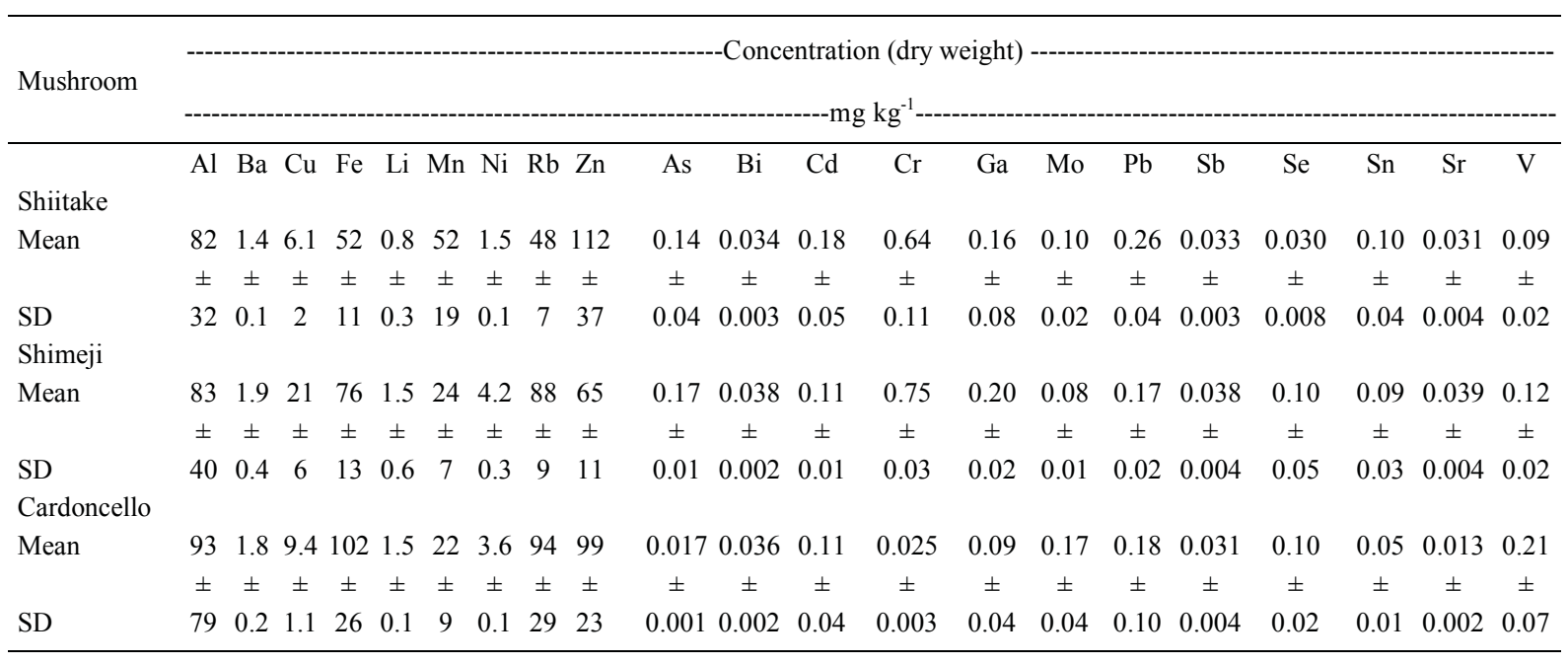

Note: Mean and standard deviation (SD) values from four sampling period. 
Table 2 - Macronutrients concentration in Shiitake, Shimeji and Cardoncello mushrooms.

\begin{tabular}{|c|c|c|c|c|}
\hline \multirow{2}{*}{ Mushroom } & \multicolumn{4}{|c|}{-----------Concentration (dry weight)----- } \\
\hline & $\mathrm{Ca}$ & $\mathrm{Na}$ & K & $\mathrm{Mg}$ \\
\hline \multicolumn{5}{|l|}{ Shiitake } \\
\hline \multirow[t]{2}{*}{ Mean } & 47 & 101 & 15000 & 4560 \\
\hline & \pm & \pm & \pm & \pm \\
\hline $\mathrm{SD}$ & 4 & 10 & 1654 & 320 \\
\hline \multicolumn{5}{|l|}{ Shimeji } \\
\hline \multirow[t]{2}{*}{ Mean } & 55 & 50 & 24585 & 2410 \\
\hline & \pm & \pm & \pm & \pm \\
\hline $\mathrm{SD}$ & 6 & 2 & 3741 & 212 \\
\hline \multicolumn{5}{|l|}{ Cardoncello } \\
\hline \multirow[t]{2}{*}{ Mean } & 59 & 65 & 17540 & 3483 \\
\hline & \pm & \pm & \pm & \pm \\
\hline $\mathrm{SD}$ & 3 & 8 & 1205 & 495 \\
\hline
\end{tabular}

Note: Mean and standard deviation (SD) values from four sampling period.

all three species of mushrooms were characterized as food with high levels of $\mathrm{Cu}, \mathrm{K}, \mathrm{Mg}, \mathrm{Mn}$ and $\mathrm{Zn}$ (Table 3). Nevertheless, considering that all levels are expressed in dry weight and the average moisture of studied species $(90 \%)$, fresh mushrooms content of minerals is relevant but the mushrooms could not be classified as major source of the analyzed elements.

Sodium mean concentration for Shimeji was $46 \mathrm{mg} \mathrm{kg}^{-1} \mathrm{dw}$, a concentration lower than
$50 \mathrm{mg} \mathrm{kg}^{-1} \mathrm{dw}$, for that reason it can be classified as a food that contains no $\mathrm{Na}$ according to Brazilian legislation (BRASIL, 1998). Shiitake (101 $\mathrm{mg} \mathrm{kg}^{-1}$ $\mathrm{dw}$ ) and Cardoncello (65 $\mathrm{mg} \mathrm{kg}^{-1} \mathrm{dw}$ ) presented $\mathrm{Na}$ mean concentrations higher than $5 \mathrm{mg} 100 \mathrm{~g}^{-1}$ and can be classified as food with low $\mathrm{Na}$ concentrations. However, $\mathrm{K}$ concentration in the three mushrooms species analyzed was high in the range of 14000$32500 \mathrm{mg} \mathrm{kg}^{-1} \mathrm{dw}$, which allows classified them as foods with high potassium content.

According to the results, $\mathrm{Na} / \mathrm{K}$ concentrations ratio in all mushrooms species were very low. The values for Shimeji $0.001871<$ Cardoncello - $0.0037058<$ Shiitake 0.0067333 were much lower than ratios of 1.11 to 1.92 which according to YANG et al. (2011) are associated with a significantly increased risk of death from cardiovascular disease in the U.S. population.

The mean Fe concentrations for Shiitake, Shimeji and Cardoncello were 52, 76 and $102 \mathrm{mg} \mathrm{kg}^{-1}$ $\mathrm{dw}$, respectively. These results were in agreement with previous studies: 13 and $33 \mathrm{mg} \mathrm{kg}^{-1} \mathrm{dw}$ for Shiitake (DE PAULI, 2010 and ÇAĞLARIRMAK, 2007), 15, 54 and $682 \mathrm{mg} \mathrm{kg}^{-1} \mathrm{dw}$ for Shimeji (ÇAĞLARIRMAK, 2007; MATTILA, 2001; GENÇCLEP et al, 2009) 31 and $355 \mathrm{mg} \mathrm{kg}^{-1} \mathrm{dw}$ for Cardoncello (MOURA, 2008; GENÇCLEP et al., 2009).

The Mo concentration represented 18$38 \%$ of RDI value (Table 3 ) and according to some studies adequate amounts of Mo are important for the prevention of esophageal cancer (PHILIP et al., 1994;

Table 3 - Comparison between the contents of total elements in the three species of mushroom with the recommended values por daily intake (RDI).

\begin{tabular}{|c|c|c|c|c|c|c|}
\hline & Adults & Shiitake & Shimeji & Cardoncello & Lower conc. & $\%$ RDI \\
\hline $\mathrm{Ca}^{1}$ & 1000 & 4.7 & 5.5 & 5.9 & 4.7 & 0.47 \\
\hline $\mathrm{Cr}^{1}$ & 0.035 & 0.064 & 0.075 & 0.0025 & 0.0025 & 7.14 \\
\hline $\mathrm{Cu}^{1}$ & 0.9 & 0.6 & 2.1 & 0.9 & 0.6 & 66.67 \\
\hline $\mathrm{Fe}^{1}$ & 14 & 5.2 & 7.6 & 10.2 & 5.2 & 37.14 \\
\hline $\mathrm{Mg}^{1}$ & 260 & 456 & 241 & 348 & 241 & 92.69 \\
\hline $\mathrm{Mn}^{1}$ & 2.3 & 5.2 & 2.4 & 2.2 & 2.2 & 95.65 \\
\hline $\mathrm{Mo}^{1}$ & 0.045 & 0.010 & 0.008 & 0.017 & 0.008 & 17.78 \\
\hline $\mathrm{Se}^{1}$ & 0.034 & 0.003 & 0.010 & 0.010 & 0.003 & 8.82 \\
\hline $\mathrm{Zn}^{1}$ & 7 & 11.2 & 6.5 & 9.9 & 6.5 & 92.86 \\
\hline $\mathrm{K}^{2}$ & 3500 & 1500 & 2458 & 1754 & 1500 & 42.86 \\
\hline $\mathrm{Na}^{2}$ & 2400 & 10.1 & 5.0 & 6.5 & 5.0 & 0.21 \\
\hline
\end{tabular}

Notes:

1- BRASIL. Resolution n⿳丷ㅜㄹ, 2005.

2- FAO 2013

3- \% RDI was calculated using the RDI values and the lower concentration of the element found in mushrooms. 
Table 4 - Maximum acceptable limits (MAL), provisional tolerable weekly intake (PTWI) and element contents in mushrooms.

\begin{tabular}{|c|c|c|c|c|c|}
\hline \multirow{2}{*}{ Element } & \multirow{2}{*}{$\mathrm{MAL}^{1} \mathrm{mg} \mathrm{kg}^{-1}$} & \multirow{2}{*}{$\mathrm{PTWI}^{2} \mathrm{mg} \mathrm{kg}^{-1}$ body weight $(\mathrm{x} 70 \mathrm{~kg})^{*}$} & \multicolumn{3}{|c|}{---------Mean values ( $\mathrm{mg} \mathrm{kg}^{-1}$ dry weight)----- } \\
\hline & & & Shiitake & Shimeji & Cardoncello \\
\hline$\overline{\mathrm{Al}}$ & & $1(70)$ & 80 & 83 & 93 \\
\hline $\mathrm{Sb}$ & 2 & & 0.003 & 0.004 & 0.003 \\
\hline As & 1 & $0.015(1.05)$ & 0.014 & 0.016 & 0.002 \\
\hline $\mathrm{Cd}$ & 1 & $0.007(0.49)$ & 0.018 & 0.010 & 0.011 \\
\hline $\mathrm{Pb}$ & 0.8 & $0.025(1.75)$ & 0.026 & 0.017 & 0.018 \\
\hline $\mathrm{Cu}$ & 30 & $3.5(245)$ & 0.6 & 2 & 0.9 \\
\hline $\mathrm{Cr}$ & 0.1 & & 0.31 & 0.36 & 0.18 \\
\hline $\mathrm{Sn}$ & 250 & $14(980)$ & 0.007 & 0.009 & 0.005 \\
\hline $\mathrm{Fe}$ & & $0.8(56)$ & 41 & 76 & 102 \\
\hline $\mathrm{Ni}$ & 5 & & 1.5 & 4 & 3.6 \\
\hline $\mathrm{Se}$ & 0.3 & & 0.003 & 0.007 & 0.009 \\
\hline $\mathrm{Zn}$ & 50 & & 11 & 6.5 & 10 \\
\hline
\end{tabular}

Notes:

${ }^{1}$ Brasil, 1965.

JECFA Reports. *Estimated body weight of an adult male.

MOHSEN et al., 2008). Mo is a cofactor of enzymes such as nitrogenase, nitrate reductase, sulphite oxidase and xanthine oxiredutase (SCHWARZ et al., 2009). Although mushrooms are consumed in small quantities in Brazil, the Mo content is a relevant composition characteristic from the studied species.

In other studies with the same mushroom species (DEMIRBAS, 2001; MATILLA, 2001; MOURA, 2008; WANG, 2001; MANZI et al., 1999; GENÇCLEP et al., 2009) the mean levels of most elements were consistent with those in the present study. It should be emphasized that different substrate composition used in each crop results in different levels of elements as proven by FIGUEIRÓ (2011) who worked with six different substrates (Straw of rice, beans, wheat, sorghum, banana leaves and corn cob). They reported a mean $\mathrm{Fe}$ concentration of $96 \mathrm{mg} \mathrm{kg}^{-1}$ in rice straw substrate and $476 \mathrm{mg} \mathrm{kg}^{-1}$ in banana leaves; a mean Mn concentration of $7.8 \mathrm{mg} \mathrm{kg}^{-1}$ in corn cob and $835 \mathrm{mg} \mathrm{kg}^{-1}$ in banana leaves and for $\mathrm{Zn}$ a mean concentration of $7.5 \mathrm{mg} \mathrm{kg}^{-1}$ in a banana leaves and $30.2 \mathrm{mg} \mathrm{kg}^{-1}$ in rice straw.

No published data were found about $\mathrm{Al}, \mathrm{Ba}, \mathrm{Bi}, \mathrm{Li}, \mathrm{Ni}, \mathrm{Sr}$ and $\mathrm{Sb}$ in Shiitake and Cardoncello and the same for Mo, Sn and V in the three mushroom species studied.

The mean concentration of $\mathrm{Sb}, \mathrm{As}, \mathrm{Cd}, \mathrm{Pb}$, $\mathrm{Cu}, \mathrm{Cr}, \mathrm{Sn}, \mathrm{Fe}, \mathrm{Ni}, \mathrm{Se}$ and $\mathrm{Zn}$ were compared with the maximum limits of tolerance for metals in mushroons or vegetables foodstuffs (Table 4) established by Brazilian legislation (BRASIL, 1965) and in general, metal concentrations were below these recommended values.

There are no recommended maximum limits of $\mathrm{Al}$ in foods in Brazil, however, significant results were observed for $\mathrm{Al}$ in mushrooms: 82 and $83 \mathrm{mg} \mathrm{kg}^{-1} \mathrm{dw}$ in Shitake and Shimeji and $93 \mathrm{mg} \mathrm{kg}^{-1}$ $\mathrm{dw}$ in Cardoncello. These values were very close to the recommended weekly intake by JECFA (Joint FAO/ WHO Expert Committee on Food Additives) $70 \mathrm{mg} \mathrm{kg}^{-1}$ of an adult male, and could represent a risk depending on the amount of ingested mushroom.

\section{CONCLUSION}

All mushrooms studied can be considered as foods with high content of $\mathrm{Cu}, \mathrm{K}, \mathrm{Mg}, \mathrm{Mn}$ and $\mathrm{Zn}$ if they are consumed dry and they have a very low $\mathrm{Na} / \mathrm{K}$ ratio. The samples do not present a health risk with $\mathrm{Pb}, \mathrm{Cd}$ and $\mathrm{As}$ once the levels presented lower than maximum limits recommended by Brazilian legislation. Since 1996 the CODEX ALIMENTARIUS, Commission of World Health Organization and Food and Agriculture Organization considered that there are a moderate data about $\mathrm{Al}$ in food. The authors endorse the importance to develop programs including the determination of this metal in several food products.

\section{REFERENCES}

BONONI, V.L.R. O cultivo de Agaricus bisporus no Brasil. In: SIMPÓSIO INTERNACIONAL SOBRE COGUMELOS,

Ciência Rural, v.44, n.5, mai, 2014. 
ALIMENTAÇÃO, SAÚDE, TECNOLOGIA E MEIO AMBIENTE NO BRASIL, 2003, Brasília, DF. Anais... Brasília: Embrapa, 2005. p.24-31.

BRASIL. Agência Nacional de Vigilância Sanitária. Portaria $n^{\circ}$ 27, de 13 de janeiro de 1998. Aprova o Regulamento Técnico referente à Informação Nutricional Complementar (declarações relacionadas ao conteúdo de nutrientes). Diário Oficial [da] República Federativa do Brasil, Poder Executivo, Brasília, DF, 16 jan. 1998. Seção1, p.9.

BRASIL. Agência Nacional de Vigilância Sanitária. Resolução RDC no 269, de 22 de setembro de 2005. Regulamento técnico sobre a ingestão diária recomendada (IDR) de proteína, vitaminas e minerais. Diário Oficial [da] República Federativa do Brasil, Poder Executivo, Brasília, DF, 23 set. 2005. Seção1, p.372.

BRASIL. Agência Nacional de Vigilância Sanitária. Decreto $n^{\circ}$ 55871 de 26 de março de 1965. Modifica o Decreto ${ }^{\circ} 50040$, de 24 de janeiro de 1961 , referente às normas reguladoras do emprego de aditivos para alimentos, alterado pelo decreto $\mathrm{n}^{\circ} 691$, de 13 de março de 1962. Diário Oficial [da] República Federativa do Brasil, Poder Executivo, Brasília, DF, 09 abr. 1965. Seção 1, p.3610.

CAĞLARIRMAK, N. The nutrientes of exotic mushrooms (Lentinula edodes and Pleurotus species) and an estimated approach to the volatile compounds. Food Chemistry, v.105, p.1188-1194, 2007.

CODEX ALIMENTARIUS. Informe de la $\mathbf{2 8}^{\mathrm{a}}$ reunion del comite del CODEX sobre aditivos alimentarios y contaminantes de los alimentos. Manila, Filipinas, 18-22 marzo 1996. Rome: FAO, 1997. Available from: ftp://ftp.fao.org/docrep/fao/meeting/005/ W1362S/W1362s.pdf. Accessed: dec 12, 2013.

DEMIRBAS, A. Concentrations of 21 elements in 18 species of mushrooms growing in the East Black Sea Region. Food Chemistry, v.75, p.453-457, 2001.

DE PAULI, P.A. Avaliação da composição química, compostos bioativos e atividade antioxidante em cogumelos comestíveis. 73 f. Dissertação (Mestrado em Ciência dos Alimentos). Programa de Pós-Graduação em Alimentos e Nutrição, Faculdade de Ciências Farmacêuticas de Araraquara, UNESP, Araraquara, São Paulo, SP. 2010.

FAO. World agriculture: towards 2015/2030. An FAO perspective. Available from: <http://www.fao.org/DOCREP/005/ Y4252E/Y4252E00.HTM>. Accessed: dec 12, 2013.

FAO. Guidance for Industry: A food Labeling Guide 914. Appendix F: Calculate the Percent Daily value for the Appropriate Nutrients. Silver Spring, 2013. Available from: <http://www.fda.gov/food/ guidanceregulation/guidancedocumentesregulatoryinformation/ labelingnutrition/ucm064928.html>. Acessed: apr 12, 2013.

FIGUEIRÓ, G.G; GRACIOLLI, L.A. Influência da composição química do substrato no cultivo de Pleurotus florida. Ciências Agrotécnicas, v.35, n.5, p.924-930, 2011. Available from: $<$ http:// www.scielo.br/pdf/cagro/v35n5/a09v35n5.pdf $>$. Acessed: dec 12, 2013. doi: $10.1590 / \mathrm{S} 1413-70542011000500009$.

GENCCLEP, H. et al. Determination of mineral contents of wildgrow edible mushrooms. Food Chemistry, v.113, p.1033-1036, 2009. Available from: <http://www.sciencedirect.com /science/ article/pii/S0308814608010340>. Acessed: dec 12, 2013.
KALAČ, P.; SVOBODA, L. A review of trace elements concentrations in edible mushrooms. Food Chemistry, v.69, p.273-281, 2000.

KALAČ, P. Trace elements contents in European species of wild growing edible mushrooms: a review for the period 2000-2009. Food Chemistry, v.122, p.2-15, 2010.

MANZI, P. et al. Nutrientes in edible mushrooms. Food Chemistry, v.65, p.477-482, 1999.

MATTILA, P. et al. Contents of vitamins, mineral elements, and some phenolic compounds in cultivated mushrooms. Journal of Agriculture Food and Chemistry, v.49, p.2343-2348, 2001.

MICHELOT, D. et al. Update on metal content profiles in mushrooms - Toxicological implications and tentative approach to the mechanisms of bioaccumulation. Toxicon, v.36, n.12, p.11972012, 1998.

MOHSEN N. et al. Nail Molybdenum and Zinc contents in populations with low and moderate incidence of esophageal cancer. Archives of Iranian Medicine, v.11, p.392, 2008.

MOURA P.L.C. Determinação de elementos essenciais e tóxicos em cogumelos comestíveis por análise por ativação com nêutrons. 2008. 105f. Dissertação (Mestrado em Tecnologia Nuclear - Aplicações) - Programa de Tecnologia Nuclear, Instituto de Pesquisas Energéticas e Nucleares, São Paulo, SP, 2008. Available from: $<$ http://www.teses.usp.br/teses/disponiveis/85/85131/tde01092009-164737/pt-br.php>. Acessed: dec 12, 2013.

PHILIP, T. et al. Prevention of esophageal cancer: the nutrition intervention trials in Linxian, China. Cancer Research, v.54, Suppl.7, p.2029-2031, 1994.

SADLER, M. Nutritional properties of edible fungi. British Nutrition Foundation Nutrition Bulletin, v.28, p.305-308, 2003.

SCHWARZ, G. et al. Molybdenum cofactors, enzymes and pathways. Nature, v.460, p.839-847, 2009.

URBEN A.F. Produção de cogumelos por meio de tecnologia chinesa modificada. 2.ed. verificada e ampliada. Brasília: Embrapa Recursos Genéticos e Biotecnologia, 2004. 151p.

VILELA, S.P. Cogumelos: mercado e comercialização. 2007. Available from: $<\mathrm{http}: / /$ www.faemg. org.br/Content.aspx?Code $=3$ 53\&ParentCode $=13 \&$ ParentPath $=$ None $; 13 \&$ ContentVersion $=C>$. Acessed: dec. 4, 2011.

WANG, D. et al. Biological efficiency and nutritional value of Pleurotus ostreatus cultivated on spent beer grain. Bioresource Technology, v.78, p.293-300, 2001.

WHO. Aluminum. In: Evaluation of certain food and contaminants. Sixty-seventh report of the Joint FAO/WHO Expert Committee on Food Additives. Bern: WHO, 2006. p. 33-45 (Technical Report Series, 940).

Arsenic. In: Seventy-second report of the Joint FAO/WHO Expert Committee on Food Additives. Bern: WHO, 2006. p. 21-37 (Technical Report Series, 959).

Cadmium. In: Sixty-fourth report of the Joint FAO/WHO Expert Committee on Food Additives. Bern: WHO, 2006. p. 26-31 (Technical Report Series, 930). 
Cooper. In:

Twenty-sixth report of the Joint FAO/ WHO Expert Committee on Food Additives. Bern: WHO, 2006. p. 31 (Technical Report Series, 683).

Inorganic Tin. In: . Sixty-seventh report of the Joint FAO/WHO Expert Committee on Food Additives. Bern: WHO, 2006. p. 40-44 (Technical Report Series, 930).

Iron. In: . Twenty-seventh report of the Joint FAO/ WHO Expert Committee on Food Additives. Bern: WHO, 2006. p. 33-45 (Technical Report Series, 696).

Lead. In: Fifth-third report of the Joint FAO/ WHO Expert Committee on Food Additives. Bern: WHO, 2006. p. 33-45 (Technical Report Series, 896).
Zinc. In:

. Twenty-sixth report of the Joint FAO/ WHO Expert Committee on Food Additives. Bern: WHO, 2006. p. 33-45 (Technical Report Series, 683).

YANG et al. Sodium and potassium intake and mortality among US adults - Prospective data from the third national health and nutrition examination survey. Archives Internal Medicine v.171, n.13, p.1183-1191, 2011. Available from: <http://dx.doi. org/10.1001/archinternmed. 2011.257>. Accessed: dec 12, 2013.

ZHU, F. et al. Assessment of heavy metals in some wild edible mushrooms collected from Yunnan Province, China. Environmental Monitoring Assessment, 2005. p.9 Published online. Available from: <http://image.sciencenet.cn/olddata/ kexue.com.cn/upload/blog/file/2010/11/2010 1117154656790525. pdf > . Accessed: dec 12, 2013. doi: 10.1007/s10661-010-1728-5. 